\title{
TMPRSS2/ERG Fusion Gene
}

National Cancer Institute

\section{Source}

National Cancer Institute. TMPRSS2/ERG Fusion Gene. NCI Thesaurus. Code C79904.

A fusion gene that results from a genetic translocation event which fuses the $5^{\prime}$ end of the androgen-regulated TMPRSS2 gene with the entire coding region of the ERG gene. The androgen-dependent expression of this fusion gene results in overexpression of ERG activity. 